\title{
Measurements of ozone and its precursor nitrogen dioxide and crop yield losses due to cumulative ozone exposures over 40 ppb (AOT40) in rural coastal southern India
}

\author{
K. Elampari • S. B. Debaje • S. Johnson Jeyakumar • \\ T. Chithambarathanu
}

Received: 29 December 2012 / Accepted: 27 September 2013 /

Published online: 12 October 2013

C The Author(s) 2013. This article is published with open access at Springerlink.com

\begin{abstract}
Measurements of ground level ozone $\left(\mathrm{O}_{3}\right)$, nitrogen dioxide $\left(\mathrm{NO}_{2}\right)$ and meteorological parameters (air temperature, relative humidity and wind speed and direction) has been made for 3 years from March 2007 to February 2010 at Nagercoil $\left(8.2^{\circ} \mathrm{N}, 77.5^{\circ} \mathrm{E}, 23 \mathrm{~m}\right.$ above sea level), an equatorial rural coastal site of southern India. The monthly average of daytime maximum of $\mathrm{O}_{3}$ concentrations ranged from 28 to 50 parts per billion (ppb) with an annual average of $19.8 \mathrm{ppb}$. Similarly, monthly average of $\mathrm{NO}_{2}$ concentration ranged from $3.4 \mathrm{ppb}$ to $7.7 \mathrm{ppb}$ with an annual average of $5.3 \mathrm{ppb}$. The monthly variation of meteorological parameters shows the little changes being a coastal site. The estimated summer crops yield losses by $1.1-$ $15.6 \%$ from present $\mathrm{O}_{3}$ concentration level associated with AOT40 index 3.1-5 ppm h.
\end{abstract}

Keywords Ground level ozone $\cdot$ Precursor $\cdot$ Atmospheric conditions $\cdot$ Crop damage

\section{Introduction}

Ground level ozone $\left(\mathrm{O}_{3}\right)$ is increasing at the rate of $0.5-2 \%$ year $^{-1}$ over the Northern Hemisphere due to increase in anthropogenic activities on the earth surface (Vingarzan 2004). The $\mathrm{O}_{3}$ on which attention has becoming increasingly focused in the context of its negative impacts on human and vegetation (Ashmore et al. 2006; Amann et al. 2008). Amann et al. (2008) reported that exposure to high $\mathrm{O}_{3}$ levels greater than 90 parts per billion (ppb) (permissible limit) hourly averages is linked to respiratory problems. Similarly, due to phytotoxic nature of $\mathrm{O}_{3}$ greater than $40 \mathrm{ppb}$ (threshold limit) has the potential to cause adverse impacts on growth and yield of agriculture and horticulture crops (Fuhrer 2009 and references

K. Elampari · T. Chithambarathanu

S.T. Hindu College, Nagercoil 629 002, India

S. B. Debaje $(\square)$

Indian Institute of Tropical Meteorology, Pune 411 008, India

e-mail: debaje@tropmet.res.in

S. J. Jeyakumar

T. B. M. L. College, Porayar 609 307, India 
therein). Further, $\mathrm{O}_{3}$ has undesirable effects on yield quality of crops that directly affect seed and fruit chemistry as well as forage nutritive value (Royal Society 2008; Booker et al. 2009).

$\mathrm{O}_{3}$ is the most important oxidant in the troposphere. It is formed through the photochemical oxidation of precursor pollutants such as nitrogen oxides $\left(\mathrm{NO}_{\mathrm{x}}=\mathrm{NO}+\mathrm{NO}_{2}\right)$, volatile organic compounds (VOC), methane $\left(\mathrm{CH}_{4}\right)$ and carbon monoxide $(\mathrm{CO})$ in the presence of sunlight. The formation $\mathrm{O}_{3}$ is controlled by $\mathrm{NO}_{x}$ in India indicates that the $\mathrm{O}_{3}$ concentration increases with increase of $\mathrm{NO}_{x}$ concentration (Lelieveld et al. 2001). The $\mathrm{O}_{3}$ precursor gases emission are mainly increasing due to increase of automobile sector. Streets et al. (2003) reported that the emission of $\mathrm{NO}_{\mathrm{x}}$ is increasing at the rate of $6.5 \%$ year ${ }^{-1}$ over the Indian region. The automobile contributes highest $34 \%$ of the total $\mathrm{NO}_{\mathrm{x}}$ emission $(4.6 \mathrm{Tg}$ ) in India between year 2000. Similarly, Ohara et al. (2007) reported that the $\mathrm{NO}_{\mathrm{x}}$ Asian emissions increased by 3 times in the year 1980-2003 with highest increase in China followed by in India. The information on $\mathrm{O}_{3}$ measurements is limited in India; the available studies have suggested that $\mathrm{O}_{3}$ concentrations can reach potentially damaging levels of crops (Mittal et al. 2007; Engardt 2008; Debaje et al. 2010). Model studies by Mittal et al. (2007) and Engardt (2008) have shown that the daytime monthly mean of $\mathrm{O}_{3}$ concentration ranges between $30 \mathrm{ppb}$ and $45 \mathrm{ppb}$ for the year 2000 over the Indian region and exceeds AOT40 index critical limit of $3 \mathrm{ppm}$ h of 3 -months growing period of agriculture crops responsible for $5 \%$ crops yield losses by $\mathrm{O}_{3}$ damage. Further, Debaje et al. (2010) estimated that the winter wheat and summer crops yield losses by $10 \%$ and $15 \%$, respectively using AOT40 index from present measured $\mathrm{O}_{3}$ pollution level in the rural India.

Emberson et al. (2009) reported that crops respond differently to $\mathrm{O}_{3}$ exposure in Asia (India in particular) than in USA and Europe underestimating crop yield losses occur at the present $\mathrm{O}_{3}$ concentration. A recent synthesis of experimental data from Asia shows that today's concentrations (40-80 ppb) of $\mathrm{O}_{3}$ cause yield losses of three staple Asian crops (wheat, rice and legumes) that vary between $5 \%$ and $48 \%, 3-47 \%$ and $10-65 \%$ respectively. Similarly, Feng and Kobayashi (2009) reported wheat yield losses by $9.7 \%$ at $\mathrm{O}_{3}$ concentration 31-50 ppb using meta-analysis study and $5 \%$ yield losses in number of crops. Wang and Mauzerall (2004) calculated that in China, Japan and South Korea 1-9\% of wheat, rice and corn yields and 23-27\% of soybean yield were lost due to 1990 levels of $\mathrm{O}_{3}$ and that losses may exceed $30 \%$ by 2020 using MOZART-2 model simulation. Van Dingenen et al. (2009) estimate economic loss for four crops (wheat, rice, maize and soybean) for the world and largest losses are found in India between US\$3 and US\$6 billion for the year 2000 and ranking highest economic losses about $22 \%$ (US\$ 4.5 billion) followed by $21 \%$ (US\$ 4.3 billion) in China.

A few scattered $\mathrm{O}_{3}$ measurements are available over the Indian southern coastal region (Nair et al. 2002; Debaje et al. 2003; David and Nair 2011; Nishanth et al. 2012). The daytime maximum of $\mathrm{O}_{3}$ concentration reaches greater than $48 \mathrm{ppb}$ during the summer season at Thumba (Trivandrum) and Kannur sites (Nair et al. 2002; David and Nair 2011; Nishanth et al. 2012). Similarly, the average maximum $\mathrm{O}_{3}$ concentrations greater than $40 \mathrm{ppb}$ at Tranquebar was reported by Debaje et al. (2003).

In this study, we present ground level ozone $\left(\mathrm{O}_{3}\right)$, nitrogen dioxide $\left(\mathrm{NO}_{2}\right)$ and meteorological parameters (air temperature, relative humidity and wind speed and direction) measured for 3 years from March 2007 to February 2010 (study period) for the first time in this region at Nagercoil, an equatorial rural coastal site on the Arabian Sea and Bay of Bengal, a southern extreme continental part of India. Diurnal, monthly and seasonal variations of $\mathrm{O}_{3}$ were studied in the light of $\mathrm{NO}_{2}$, temperature, relative humidity, wind speed and direction and prevailing atmospheric conditions. The crops yield losses estimated in summer season due to cumulative $\mathrm{O}_{3}$ exposures over 40 ppb using AOT40 index is discussed. 


\section{Location of site, measurement techniques and method}

\subsection{Description of site}

Figure 1 presents a map of India showing measuring site-Nagercoil $\left(8.2^{\circ} \mathrm{N}, 77.5^{\circ} \mathrm{E}, 23 \mathrm{~m}\right.$ above sea level), and a few other sites which are located around it and mentioned in the present study. The population of the Nagercoil town was around 0.35 million as per 2011 census. There is no industrial complex located in the town. However, registered vehicles about 0.25 million in district Kanyakumari, Tamil Nadu state as on 1 April 2010 (STA 2010).

\subsection{General meteorology}

The month April is the representative for the summer season (March-May). The bright sunshine hours are experiences during these 3 months. The sunshine duration was longer (12.74 h/day)

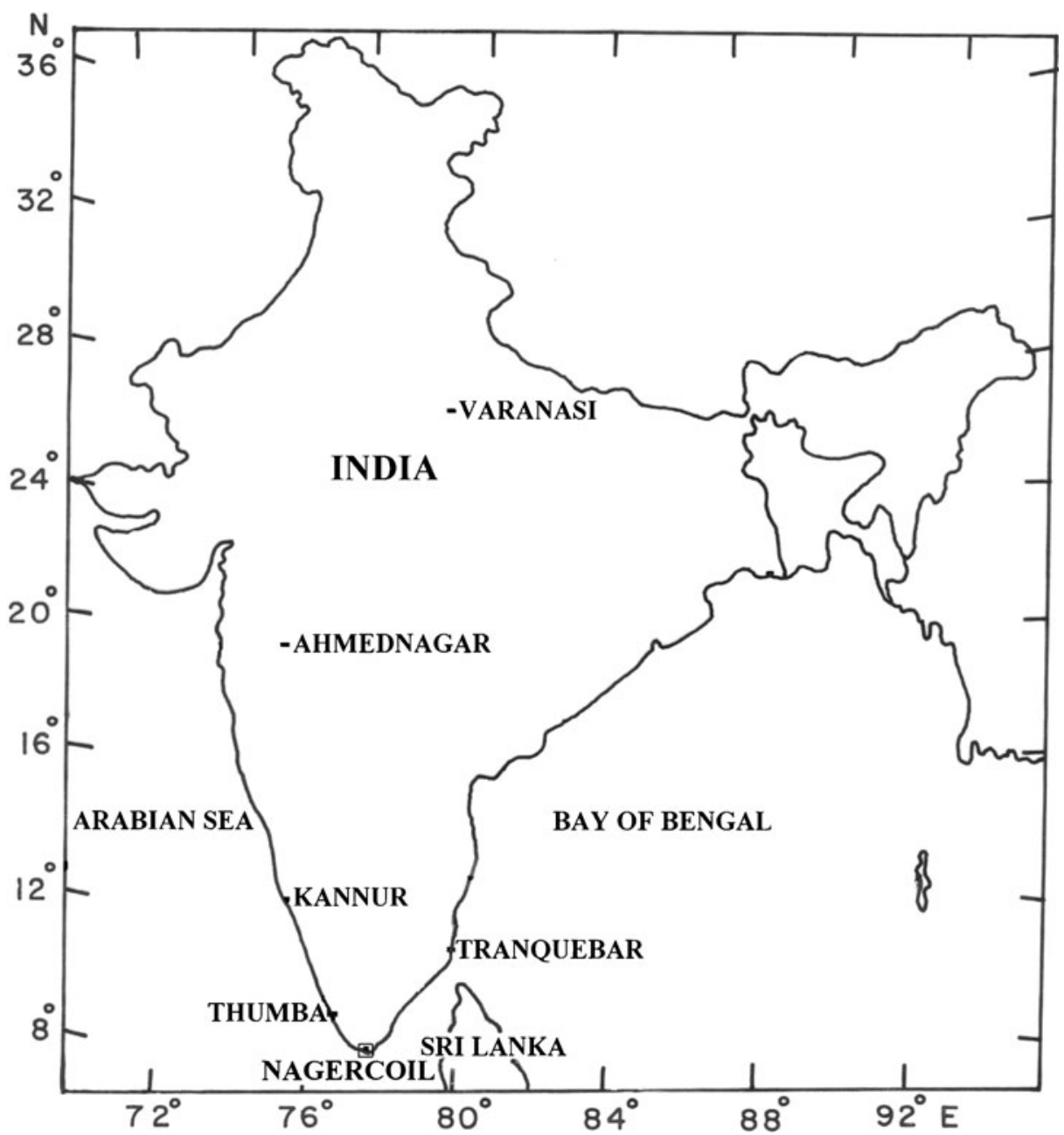

Fig. 1 Map of India shows the measurements site-Nagercoil and some other adjacent sites used in the study 
during April and shorter (5.74 h/day) during November (CGWB 2008). Table 1 shows the atmospheric conditions observed during the study period at Nagercoil. The average highest maximum (minimum) temperature $31.5^{\circ} \mathrm{C}\left(26.4^{\circ} \mathrm{C}\right)$ in April, and lowest $30^{\circ} \mathrm{C}\left(24.3^{\circ} \mathrm{C}\right)$ was in January during winter season indicating less variation in temperature being a coastal site. The hot and cloudy weather with moderate rainfall prevails during pre-monsoon season (JuneSeptember). Nagercoil receives rainfall both from northeast (NE) monsoon (OctoberDecember) and southwest (SW) monsoon (June-September); however, it seems that NE monsoon is more active than the SW monsoon. The month November is a rainiest month during NE monsoon season. The total annual normal rainfall is $83 \mathrm{~cm}$ reported by the nearest observatory Kanyakumari $\left(8.1^{\circ} \mathrm{N}, 77.5^{\circ} \mathrm{E}, 37 \mathrm{~m}\right.$ above sea level), India Meteorological Department (IMD) (http://www.imd.gov.in). Fair weather conditions prevail in the month of February is the representative for the winter season (January-February). The surface meteorological parameters such as cloud cover and rainfall are used from Kanyakumari observatory to explore their role on $\mathrm{O}_{3}$ formation (Debaje et al. 2003; IMD 2010).

\subsection{Measurement techniques}

Measurement of $\mathrm{O}_{3}, \mathrm{NO}_{2}$ in parts per billion (ppb) and meteorological parameters were carried out using the Aeroqual Series 200 Handheld Monitor (Aeroqual Limited, New Zealand) at Nagercoil, India. The more details about the instrument are available at website www.aeroqual.com. Gas Sensitive Semiconductor (GSS) technology is used to measured the gases. The sensor head is controlled by intelligent data logger. The operating chemical parameters are $\mathrm{O}_{3}$ (detection range $0-500 \mathrm{ppb}$ ) and $\mathrm{NO}_{2}$ (detection range 0-200 ppb). The lower detection limit for $\mathrm{O}_{3}$ and $\mathrm{NO}_{2}$ is 1 ppbv and response time for $\mathrm{O}_{3}$ less than $70 \mathrm{~s}$ and $\mathrm{NO}_{2}$ less than $60 \mathrm{~s}$. The meteorological parameters such as air temperature $\left({ }^{\circ} \mathrm{C}\right)$, relative humidity $(\%)$ and wind speed $\left(\mathrm{ms}^{-1}\right)$ and direction (16 points compass) are also measured using different sensors. The lower detection limit for temperature sensor is $0.01{ }^{\circ} \mathrm{C}$ and for relative humidity sensor $1 \%$ and response time less than $1 \mathrm{~s}$. All times are given in Indian Standard Time (IST), which is ahead of the GMT by 05:30 h. The $\mathrm{O}_{3}$ sensor was calibrated with the ultraviolet (UV) photometric $\mathrm{O}_{3}$ analyzer (Model: $\mathrm{O}_{3} 42 \mathrm{M}$, Environmental S. A., France) by running them together with averaging time interval of $1 \mathrm{~h}$, and correlation coefficient is found to be $0.86-$ 0.94. Similarly, $\mathrm{NO}_{2}$ sensor was calibrated with the chemiluminescence's technique (Model: APNA 365 analyzer, Horiba, Japan) by running them together with averaging time interval of $1 \mathrm{~h}$, and correlation coefficient is $0.84-0.91$.

All data analyses in this study are based upon the hourly averaged of $\mathrm{O}_{3}, \mathrm{NO}_{2}$, temperature, relative humidity and wind speed and direction. The daily means of $\mathrm{O}_{3}, \mathrm{NO}_{2}$, temperature, relative humidity and wind speed and direction was calculated from the hourly average. The monthly average of $\mathrm{O}_{3}, \mathrm{NO}_{2}$, temperature, relative humidity and wind speed and direction was calculated from the daily mean for each month. The monthly average daytime maximum value of $\mathrm{O}_{3}$ was calculated from averaging daily single maximum values of $\mathrm{O}_{3}$ concentration for each month. The monthly diurnal means of $\mathrm{O}_{3}, \mathrm{NO}_{2}$, temperature and relative humidity was computed by averaging for all days of a month for specific hour. The annual and seasonal diurnal means of $\mathrm{O}_{3}$ are computed by averaging for all months of a year.

\subsection{Method}

Crop yield losses due to cumulative $\mathrm{O}_{3}$ exposures over 40 ppb was estimated using AOT40 index (accumulated $\mathrm{O}_{3}$ concentration over a threshold of $40 \mathrm{ppb}$ ) (Mills et al. 2007). AOT40 is the hourly mean $\mathrm{O}_{3}$ concentration accumulated over a threshold $\mathrm{O}_{3}$ concentration of 


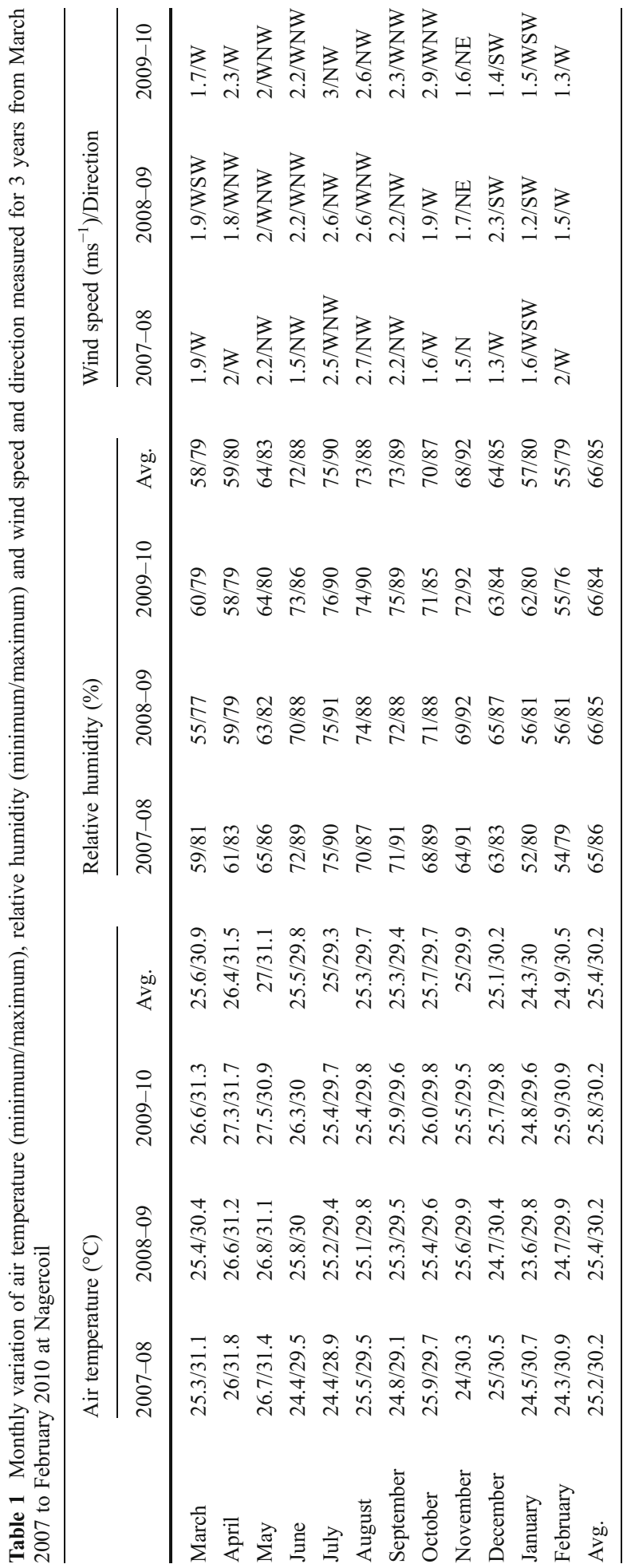


$40 \mathrm{ppb}$ during daylight hours for 3-months of growing (November-December) to harvesting (March-April) period for agricultural and horticulture crops and is linearly correlated with crop yield reduction, unit's parts per million hours ( $\mathrm{ppm}$ h, hourly average). AOT40 is calculated mathematically as (Engardt 2008):

$$
\text { AOT40 }=\sum_{\mathrm{i}=1}^{\mathrm{n}}\left(\left[\mathrm{O}_{3}\right]-40\right) \mathrm{i} \text { for }\left[\mathrm{O}_{3}\right]>40 \mathrm{ppb} \text { during daylight hours }
$$

$\left[\mathrm{O}_{3}\right]=$ hourly averaged $\mathrm{O}_{3}$ concentration in ppb; $40=$ threshold limit of $\mathrm{O}_{3}$ and $\mathrm{n}$ is the number of hours from growing to harvesting season of crop.

\section{Results and discussion}

\subsection{Diurnal variation}

Figure 2a shows the annual average diurnal variations of $\mathrm{O}_{3}$ for the 3 years 2007, 2008 and 2009. The highest and lowest concentration of $\mathrm{O}_{3}$ was observed in April and November, respectively; hence, it is investigated separately in Fig. $2 b$. The annual average daytime maximum of $\mathrm{O}_{3}$ concentration $33.3 \pm 8,30.3 \pm 8$ and $34.6 \pm 10 \mathrm{ppb}$ in the afternoon around 15:00 $\mathrm{h}$ and minimum of $\mathrm{O}_{3} 9.1 \pm 5,9 \pm 5$ and $9.8 \pm 7 \mathrm{ppb}$ at the sunrise $06: 00 \mathrm{~h}$ with $1 \sigma$ standard deviation in 2007, 2008 and 2009, respectively (Fig 2a). The highest maximum of $\mathrm{O}_{3}$ concentration $49.7 \pm 17 \mathrm{ppb}(27.7 \pm 8 \mathrm{ppb})$ (average for 3 years) was observed in the afternoon and minimum of $\mathrm{O}_{3} 16.5 \pm 11 \mathrm{ppb}(8.1 \pm 6 \mathrm{ppb})$ at the sunrise in April (November) (Fig. 2b). It was observed that hourly averaged daytime highest maximum of $\mathrm{O}_{3}$ exceeds $75 \mathrm{ppb}$ in the afternoon in April attributed to the high temperature and clear sky along with high $\mathrm{NO}_{2}$ concentration (favorable conditions for $\mathrm{O}_{3}$ formation).

The daytime maximum of $\mathrm{O}_{3}$ concentration was observed between 14:00 h and 16:00 h, and corresponding maximum air temperature attained between 13:00 $\mathrm{h}$ and 15:00 h indicating peak $\mathrm{O}_{3}$ concentration lagged behind nearly by $1-2 \mathrm{~h}$ from peak air temperature (Figs. 2 and 4 ). Debaje and Kakade (2009) reported the similar time lag from peak air temperature to peak $\mathrm{O}_{3}$ concentration at continental rural site. Similarly, the maxima of $\mathrm{O}_{3}$ concentration were always observed in the afternoon in all seasons similar to other coastal rural sites in southern India, a characteristic of rural site (Nair et al. 2002; Debaje et al. 2003; David and Nair 2011; Nishanth et al. 2012).

Figure 3a, b shows the annual average diurnal variation of $\mathrm{NO}_{2}$ for 3 years 2007, 2008 and 2009, and diurnal variation in April and November. It is seen from the Fig. 3a that highest $\mathrm{NO}_{2}$ concentration 6.5, 6.5 and $6.6 \mathrm{ppb}$ was observed at around midnight 24:00 $\mathrm{h}$ and minimum of $\mathrm{NO}_{2} 1.7,1.8$ and $2.8 \mathrm{ppb}$ in the afternoon at 15:00 $\mathrm{h}$ in 2007, 2008 and 2009, respectively. The maximum of $\mathrm{O}_{3}$ concentration formed at around 15:00 h, and corresponding minimum of $\mathrm{NO}_{2}$ observed at the same time indicate that $\mathrm{NO}_{2}$ utilized in the $\mathrm{O}_{3}$ formation. The significant year to year differences in annual diurnal $\mathrm{NO}_{2}$ variation were not observed in 3 years period, however, higher $\mathrm{NO}_{2}$ concentration was observed in 2009 than $\mathrm{NO}_{2}$ concentration in 2007 and 2008. The maximum $\mathrm{NO}_{2}$ concentration $8.5 \mathrm{ppb}(4.2 \mathrm{ppb})$ was observed in the midnight and the minimum of $\mathrm{NO}_{2} 3.2 \mathrm{ppb}(0.9 \mathrm{ppb})$ in the afternoon in April (November) (Fig. 3b). It is to be noted that the small upper side kink in the diurnal pattern of $\mathrm{NO}_{2}$ were observed at around 9:00 $\mathrm{h}$ due to morning rush hours of traffic emission.

The high concentration of $\mathrm{NO}_{2}$ in April was due to biomass burning and low $\mathrm{NO}_{2}$ in November because of rainy season. The biomass burning from March to May in India results 
Fig. 2 Annual average diurnal variations of ozone concentration (ppb) observed at Nagercoil for 2007, 2008 and 2009 (a) and average diurnal variations of ozone concentration in April and November (b). Note that Y-axis scale is different for $b$
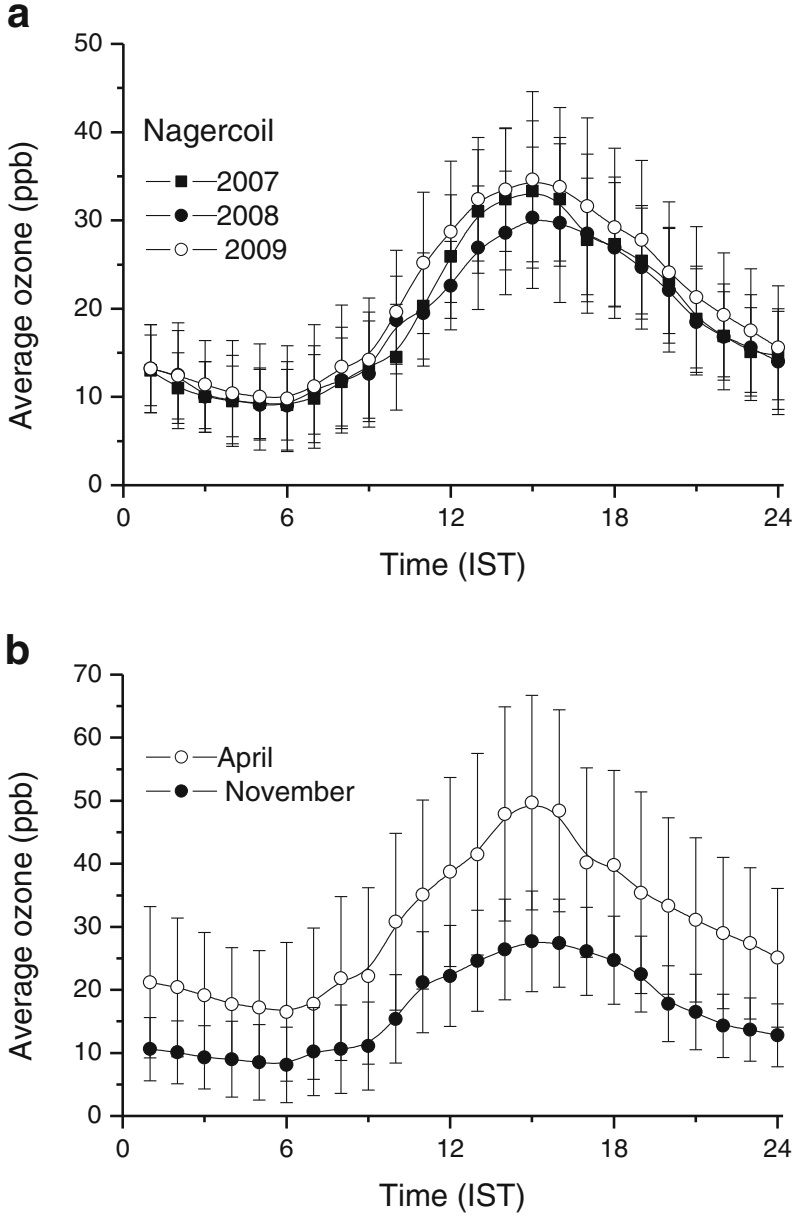

in emission of $\mathrm{NO}_{\mathrm{x}}$ and $\mathrm{VOC}$ lead to more photochemical buildup of $\mathrm{O}_{3}$ in rural areas (Galanter et al. 2000). Further, the emissions of biogenic hydrocarbons (e.g. isoprene) increases with increase of temperature help produce more $\mathrm{O}_{3}$ in summer season (Velasco 2003). Similarly, Figs. 4a, b and 5a, b show the annual average diurnal variation of temperature and relative humidity, respectively, and diurnal variation in April and November. The annual maximum temperature around $30.1{ }^{\circ} \mathrm{C}, 30.2{ }^{\circ} \mathrm{C}$ and $30.4{ }^{\circ} \mathrm{C}$ was observed in the afternoon $(14: 00-15: 00 \mathrm{~h})$ and minimum of $25.5^{\circ} \mathrm{C}, 25.4{ }^{\circ} \mathrm{C}$ and $25.6{ }^{\circ} \mathrm{C}$ in the morning $(6: 00 \mathrm{~h})$ in 2007, 2008 and 2009, respectively (Fig. 4a). The maximum temperature $31.7^{\circ} \mathrm{C}\left(29.8^{\circ} \mathrm{C}\right)$ was observed in the afternoon around 15:00 $\mathrm{h}$ and minimum of $27.3{ }^{\circ} \mathrm{C}\left(25.5{ }^{\circ} \mathrm{C}\right)$ in the morning 6:00 $\mathrm{h}$ in April (November) (Fig. 4b). The highest temperature greater than $36{ }^{\circ} \mathrm{C}$ were also observed on clear sky days in April, related to highest $\mathrm{O}_{3}$ formation. The highest relative humidity was observed in November and lowest in April, related to lowest $\mathrm{O}_{3}$ concentration in November because photochemical formation of $\mathrm{O}_{3}$ decreases with increase of relative humidity and overcast sky (unfavorable conditions for $\mathrm{O}_{3}$ formation) (Debaje et al. 2003). The westerly wind of the order of $2-2.3 \mathrm{~ms}^{-1}$ was in April favor for high $\mathrm{O}_{3}$ concentration; while northeasterly wind $1.5-1.7 \mathrm{~ms}^{-1}$ in November decreases $\mathrm{O}_{3}$ concentration (Table 1). 
Fig. 3 Annual average diurnal variations of nitrogen dioxide $\left(\mathrm{NO}_{2}\right)$ concentration (ppb) observed at Nagercoil for 2007 , 2008 and 2009 (a) and average diurnal variations of nitrogen dioxide concentration in April and November (b)
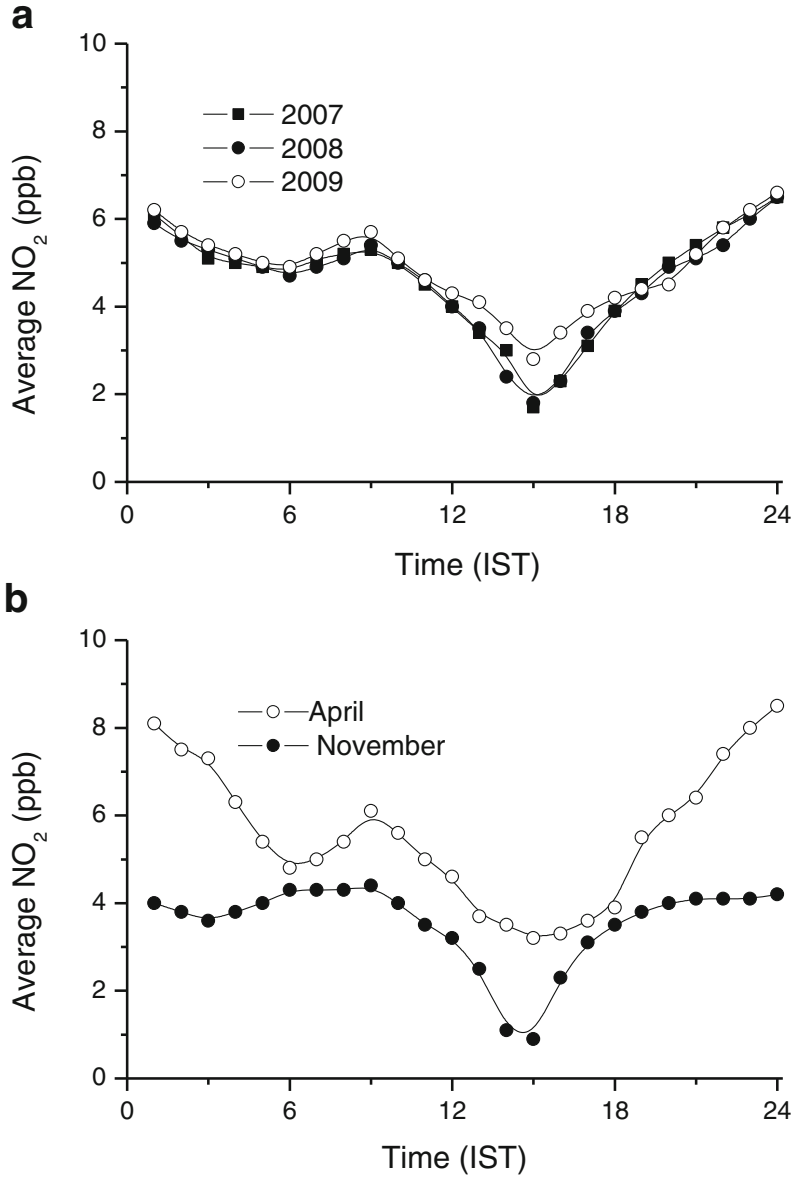

\subsection{Seasonal variation}

Table 2 shows the comparison of monthly average $\mathrm{O}_{3}$ concentration at Nagercoil and other nearby coastal sites $\mathrm{O}_{3}$ measured available in India. The monthly average of $\mathrm{NO}_{2}$ measured also shown in Table 2. The highest average of $\mathrm{O}_{3}$ concentration in the range 24.9-27.9 ppb was observed in April. The corresponding average highest $\mathrm{NO}_{2}$ concentration $6.8 \mathrm{ppb}$ was in April indicating that $\mathrm{O}_{3}$ increases with increase of $\mathrm{NO}_{2}$. The lowest $\mathrm{O}_{3}$ concentration 14.4$16.9 \mathrm{ppb}$ was observed in November and corresponding lowest $\mathrm{NO}_{2}$ concentration about $4 \mathrm{ppb}$ indicate that the $\mathrm{O}_{3}$ decreases with decrease of $\mathrm{NO}_{2}$ concentration. The annual averaged $\mathrm{O}_{3}$ concentration was $19.8 \mathrm{ppb}$ for the study period with highest annual $\mathrm{O}_{3}$ concentration $20.6 \mathrm{ppb}$ in 2009 followed by $19.7 \mathrm{ppb}$ and19.2 ppb in 2007 and 2008, respectively. The rate of increase of $\mathrm{O}_{3}$ is $2.4 \%$ year $^{-1}$ for the study period, which is higher than the $\mathrm{O}_{3}$ increase rate 1.45 year $^{-1}$ during 1954-55 and 1991-93 in Ahmedabad, India reported by Naja and Lal (1996).

Similarly, annual averaged $\mathrm{NO}_{2}$ concentration 5.3 ppb was for 3 years period with highest annual $\mathrm{NO}_{2}$ concentration $5.8 \mathrm{ppb}$ in 2009. The higher annual average $\mathrm{O}_{3}$ concentration in 2009 than in 2007 (4.6 ppb) and 2008 (5.6 ppb) was due to the higher $\mathrm{NO}_{2}$ concentration in 2009. The rate of increase of $\mathrm{NO}_{2}$ is $8.6 \%$ year ${ }^{-1}$ for the study period, which is also higher 
Fig. 4 Annual average diurnal variations of air temperature $\left({ }^{\circ} \mathrm{C}\right)$ observed at Nagercoil for 2007, 2008 and 2009 (a) and average diurnal variations of air temperature in April and November (b). Note that Y-axis scale is different for $b$
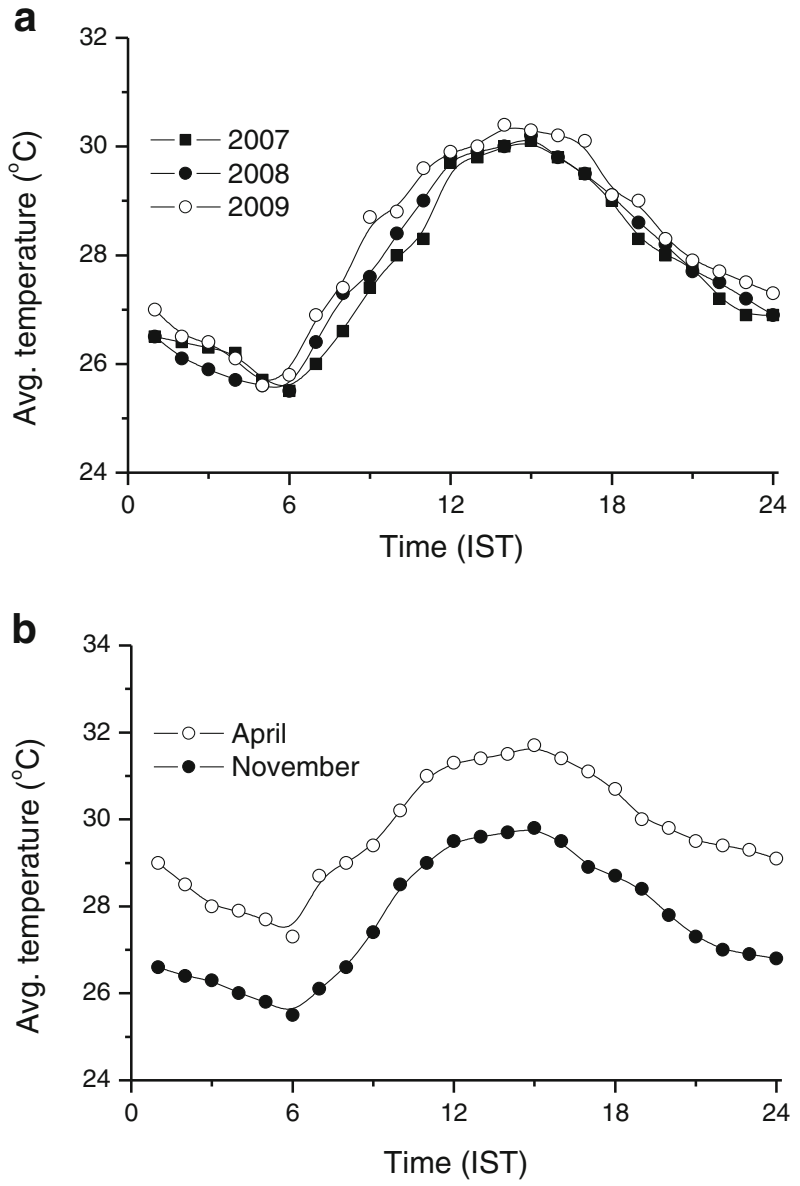

than the rate of increase of $\mathrm{NO}_{\mathrm{x}} 6.5 \%$ year $^{-1}$ in India between 2000 reported by Streets et al. (2003). The $\mathrm{O}_{3}$ concentrations linearly depend on emission of $\mathrm{NO}_{\mathrm{x}}$ in the rural sites (Wang et al. 2001). It is seen from the Table 2 that $\mathrm{O}_{3}$ measured at Nagercoil is in good agreement on seasonal basis with $\mathrm{O}_{3}$ measured at Thumba. Similarly, $\mathrm{O}_{3}$ measured at Nagercoil are in good agreement with the $\mathrm{O}_{3}$ measured in April and in November at Tranquebar and Kannur.

\section{Crop exposure to $\mathrm{O}_{3}$}

The monthly average daytime maximum of $\mathrm{O}_{3}$ concentration was 37.8, 42.1, 45.4, 43 and $40.2 \mathrm{ppb}$ in February, March, April, May and June in 2007, respectively. The 3-months cumulative mean $\mathrm{O}_{3}$ concentration was $41.8,43.5$ and 42.9 ppb for February-April, MarchMay and April-June 2007. Similarly, monthly daytime maximum $\mathrm{O}_{3}$ concentration 39, 40.3, 43.9, 41.7 and 40.2 ppb in February, March, April, May and June in 2008, respectively. The 3months cumulative mean $\mathrm{O}_{3}$ concentration was 41, 42 and 41.9 ppbv for February-April, March-May and April-June 2008, respectively. The monthly daytime maximum $\mathrm{O}_{3}$ concentration 38.4, 42.2, 59.3, 46.5 and 39.5 ppb in February, March, April, May and June in 2009, respectively. The 3-months cumulative mean $\mathrm{O}_{3}$ concentration was 46.6, 49.3 and $48.4 \mathrm{ppb}$ for 
Fig. 5 Annual average diurnal variations of relative humidity (RH) (\%) observed at Nagercoil for 2007, 2008 and 2009 (a) and average diurnal variations of relative humidity in April and November (b)
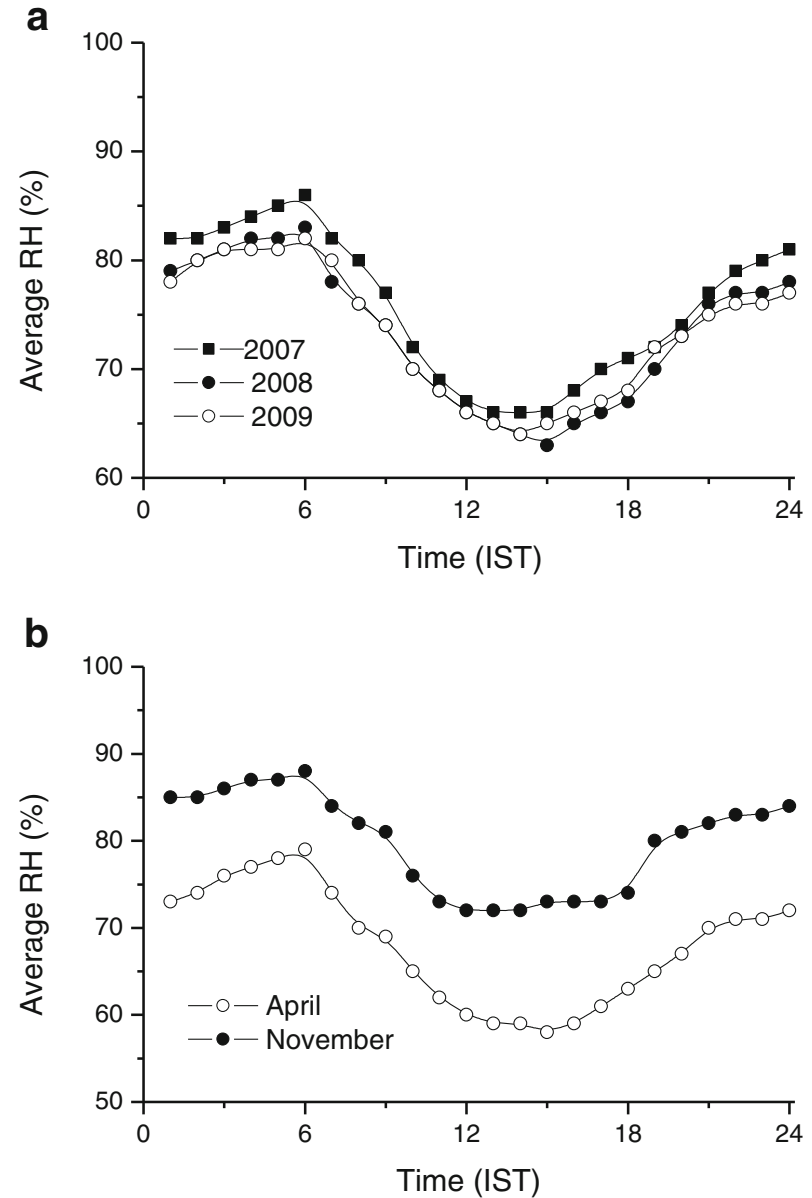

February-April, March-May and April-June 2009, respectively indicating crop yield losses due to $\mathrm{O}_{3}$ exposure. The daytime hourly averaged $\mathrm{O}_{3}$ concentration less than threshold limits of 40 ppb was observed from July to January each year for 2007, 2008 and 2009.

\subsection{AOT40 index}

The monthly AOT40 index value was calculated using Equation (1) from February to June in 2007, 2008 and 2009. Further, cumulative 3-months AOT40 value was calculated for different period such as February-April, March-May and April-June. Table 3 shows the summary of calculated AOT40 index values for the different period. The highest AOT40 index value was $3.1 \mathrm{ppm} \mathrm{h}, 2.6 \mathrm{ppm}$ h and 5 ppm h in March-May 2007, March-May 2008 and March-May 2009, respectively used for estimation of crop yield losses due to $\mathrm{O}_{3}$ damage. The AOT40 critical limits for $5 \%$ crop yield losses for $\mathrm{O}_{3}$ sensitive crops (watermelon, pulses (black gram (urd) and red gram (tur), green gram (moong)), cotton, wheat, onion, tomato) and moderately sensitive crops (oilseeds (groundnut, caster), potato, rice and maize) are used from Mills et al. (2007). The different AOT40 critical limits for $5 \%$ crops losses for different crops: watermelon, pulses, cotton, wheat, onion, tomato, oilseeds, 


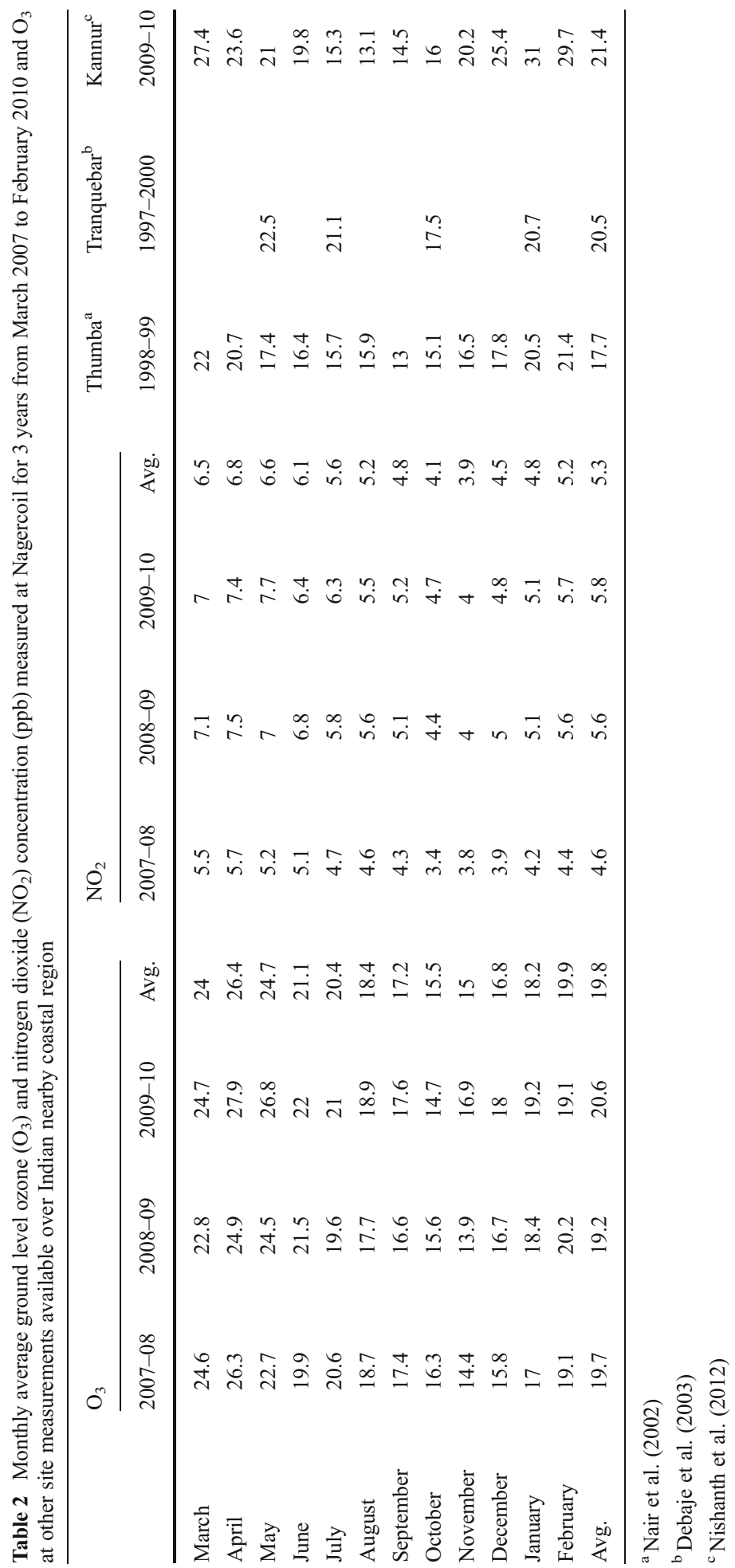


Table 3 AOT40 index calculated during different months in 2007 , 2008 and 2009

\begin{tabular}{lc}
\hline Period & AOT40 (ppm h) \\
\hline March 2007 to May 2007 & 3.1 \\
April 2007 to June 2007 & 1.8 \\
February 2008 to April 2008 & 1.2 \\
March 2008 to May 2008 & 2.6 \\
April 2008 to June 2008 & 1.4 \\
February 2009 to April 2009 & 3.5 \\
March 2009 to May 2009 & 5 \\
April 2009 to June 2009 & 2.7 \\
\hline
\end{tabular}

potato, rice and maize are 1.6, 3, 3.1, 3.3, 4.1, 6, 8.9, 8.9, 12.8 and $13.9 \mathrm{ppm} \mathrm{h}$, respectively. Large number of varities of agriculture and horticulture crops is grown over this area which is $\mathrm{O}_{3}$ sensitive and moderately sensitive to $\mathrm{O}_{3}$. In addition to the above crops, millets (bajara, ragi, jowar (sorghum, sweet sorghum), sesame, bean, jute, tea, coffee, sugarcane, mangoes, bananas, orange, grape, pepper, cardamom, chilies, cashew nut, coconut and natural rubber are also grown (http://www.tnau.ac.in/tech/acpen.pdf).

Table 4 shows the estimated crop yield losses for different crops using highest AOT40 index value in 2007, 2008 and 2009. The crops yield losses ranged from $1.1 \%$ to $9.7 \%, 0.9-8.1 \%$ and 1.8-15.6\% in 2007, 2008 and 2009 associated with AOT40 index values $3.1 \mathrm{ppb} \mathrm{h}$, $2.6 \mathrm{ppb}$ h and $5 \mathrm{ppb}$ h, respectively indicate that highest crops yield losses in 2009 . The higher crop yield losses were observed for $\mathrm{O}_{3}$ sensitive crops than for moderately sensitive crops. The crops yield losses is highest for watermelon $(9.7 \%)$, followed by pulses $(5.2 \%)$, cotton $(5 \%)$ and wheat (4.7\%) in 2007. The crops yield loss is low in 2008 compared to crops yield loss in 2007 and 2009. The highest watermelon yield losses by $15.6 \%$, while pulses and wheat losses by $8.3 \%$ and $7.6 \%$, respectively was observed in 2009 . It is seen from the above estimation that AOT40 index values exceed critical limit for $5 \%$ yield losses of crop which are $\mathrm{O}_{3}$ sensitive during March-May indicating that the present $\mathrm{O}_{3}$ concentration has negative effects on crop yield due to $\mathrm{O}_{3}$ exposure in summer season.

The stomatal conductance is higher in hot and humid environments in Asia, particularly in India poses more damage to crops due to $\mathrm{O}_{3}$ exposure than in hot and dry environments in some

Table 4 Estimated crops yield losses $(\%)$ due to $\mathrm{O}_{3}$ exposure using AOT40 index in 2007, 2008 and 2009

\begin{tabular}{llll}
\hline Crops/years & 2007 & 2008 & 2009 \\
\hline $\begin{array}{l}\text { Sensitive to } \mathrm{O}_{3} \\
\quad \text { Watermelon }\end{array}$ & 9.7 & 8.1 & \\
Pulses & 5.2 & 4.3 & 15.6 \\
Cotton & 5 & 4.2 & 8.3 \\
Wheat & 4.7 & 4.2 & 8 \\
Onion & 3.8 & 3.9 & 7.6 \\
Tomato & 2.6 & 2.2 & 6.1 \\
Moderately sensitive to $\mathrm{O}_{3}$ & & 4.2 \\
Oilseed & 1.7 & 1.4 & \\
Potato & 1.7 & 1.4 & 2.8 \\
Rice & 1.2 & 1 & 2.8 \\
Maize & 1.1 & 0.9 & 1.9 \\
\hline
\end{tabular}


areas of Europe and USA (Fiscus et al. 2005). Further, crops sensitive to $\mathrm{O}_{3}$ are at more risk due to likely co-occurrence of peak levels of $\mathrm{O}_{3}$ and growing period of these crops from February to May. Winter wheat is especially sensitive to $\mathrm{O}_{3}$ in India due to the likely co-occurrence of peak levels of $\mathrm{O}_{3}$ and growing season (Emberson et al. 2003). The estimated crop yield losses by $1.1-15.6 \%$ using AOT40 index due to $\mathrm{O}_{3}$ damage at Nagercoil similar to other locations in India and Asia (Wahid 2006; Rai et al. 2007; Debaje et al. 2010). Wahid (2006) estimate reductions of $43 \%, 39 \%$ and $18 \%$ in seed weight plant ${ }^{-1}$ of Pasban 90, Punjab 96 and Inqilab 91 varieties of wheat, respectively at seasonal mean $\mathrm{O}_{3}$ concentration of 70 ppb by experimental study in Lahore, Pakistan. Rai et al. (2007) reported winter wheat yield losses by $21 \%$ using open top chambers study for $\mathrm{O}_{3}$ concentration of $42 \mathrm{ppb}$ at Varanasi, India.

The $\mathrm{NO}_{2}$ is increasing at the rate of $8.6 \%$ year $^{-1}$ at Nagercoil due to growth of automobiles sector, where no restrictive measures on emissions of $\mathrm{O}_{3}$ precursors (particularly $\mathrm{NO}_{\mathrm{x}}$ ) were assumed to be implemented. The elevated $\mathrm{O}_{3}$ concentration in future has direct negative effects on crops yield production threatening the food security in India. We use the AOT40-yield response functions obtained in Europe to estimate crop production losses in the present study. The $\mathrm{O}_{3}$ exposure-response relationships function not established in India due to limited experiments, hence, no alternative approach is possible. Our results suggest that future crop yield reductions due to $\mathrm{O}_{3}$ damage will be large, if no mitigation efforts for $\mathrm{O}_{3}$ precursor are implemented.

\section{Conclusions}

Measurements of $\mathrm{O}_{3}, \mathrm{NO}_{2}$, temperature, relative humidity, wind speed and direction was made during 2007-2010 at Nagercoil, a rural coastal site in India clearly revealed that the $\mathrm{O}_{3}$ concentration was higher in April than in November attributed to high $\mathrm{NO}_{2}$ concentration, high temperature and low relative humidity. The monthly average of daytime maximum of $\mathrm{O}_{3}$ concentrations ranged from $28 \mathrm{ppb}$ to $50 \mathrm{ppb}$ with an annual increase rate of $\mathrm{O}_{3}$ is $2.4 \%$. Similarly, monthly average of $\mathrm{NO}_{2}$ concentration ranged from $3.4 \mathrm{ppb}$ to $7.7 \mathrm{ppb}$ with an annual increase rate of $\mathrm{NO}_{2}$ is $8.6 \%$. The estimated summer crops yield losses by $1.1-15.6 \%$ associated with AOT40 index values 3.1-5 ppm h. This study suggests that ambient $\mathrm{O}_{3}$ pollution in areas of Nagercoil has potential negative impact on crop growth and yield during the summer season. We feel that more such extensive observations of $\mathrm{O}_{3}$ and its precursor are needed to understand the effect of $\mathrm{O}_{3}$ on crop yield losses.

Acknowledgments We are thankful to the Director, Indian Institute of Tropical Meteorology, Pune for his encouragement to carry out this study. It is our pleasure to acknowledge University Grant Commission, Government of India for sponsoring the minor project to carry out $\mathrm{O}_{3}$ measurements at Nagercoil rural coastal site.

Open Access This article is distributed under the terms of the Creative Commons Attribution License which permits any use, distribution, and reproduction in any medium, provided the original author(s) and the source are credited.

\section{References}

Amann, M., Derwent, D., Forsberg, B., Hanninen, O., Hurley, F., Krzyzanowski, M., de Leeuw, F., Liu, S.J., et al.: Health Risks of Ozone From Long-Range Transboundary Air Pollution. World Health Organization, Europe (2008)

Ashmore, M., Toet, S., Emberson, L.: Ozone - a significant threat to future world food production? New Phytol. 170, 201-204 (2006) 
Booker, F., Muntifering, R., McGrath, M., Burkey, K., Decoteau, D., Fiscus, E., Manning, W., Krupa, S., et al.: The ozone component of global change: potential effects on agriculture and horticultural plant yield, product quality and interactions with invasive species. J. Integr. Plant Biol. 51(4), 337-351 (2009)

CGWB, Central Ground Water Board: Technical report on District Groundwater Brochure, Kanyakumari District, Tamil Nadu state, South Eastern Coastal Region, Chennai, Ministry of Water Resources, Government of India (2008)

David, L.M., Nair, P.R.: Diurnal and seasonal variability of surface ozone and NOx at a tropical coastal site: association with mesoscale and synoptic meteorological conditions. J. Geophys. Res. 116, D10303 (2011). doi:10.1029/2010JD015076

Debaje, S.B., Johnson, J.S., Ganesan, K., Jadhav, D.B., Seetaramayya, P.: Surface ozone measurements at tropical rural coastal station Tranquebar. India. Atmos. Environ. 37, 4911-4916 (2003)

Debaje, S.B., Kakade, A.D.: Surface ozone variability over western Maharashtra. India. J. Hazard. Mater. 161, 686-700 (2009)

Debaje, S.B., Kakade, A.D., Johnson Jeyakumar, S.: Air pollution effect of $\mathrm{O}_{3}$ on crop yield in rural India. J. Hazard. Mater. 183, 773-779 (2010)

Emberson, L.D., Ashmore, M.R., Murray, F.: Air Pollution Impacts on Crops and Forests: A Global Assessment. Imperial College Press, London (2003)

Emberson, L.D., Buker, P., Ashmore, M.R., Mills, G., Jackson, L.S., Agrawal, M., Atikuzzaman, M.D., Cinderby, S., et al.: A comparison of North American and Asian exposure-response data for ozone effects on crop yields. Atmos. Environ. 43, 1945-1953 (2009)

Engardt, M.: Modeling of near-surface ozone over South Asia. J. Atmos. Chem. 59, 61-80 (2008). doi:10.1007/s10874-008-9096-Z

Feng, Z., Kobayashi, K.: Assessing the impacts on current and future concentrations of surface ozone on crop yield with meta-analysis. Atm Environ 43, 1510-1519 (2009)

Fiscus, E.L., Fitzgarrald, L.B., Burkey, K.O.: Crop responses to ozone: uptake, modes of action, carbon assimilation and partitioning. Plant Cell and Environ. 28, 997-1011 (2005)

Fuhrer, J.: Ozone risk for crops and pastures in present and future climates. Naturwissenschaften 96, 173-194 (2009)

Galanter, M., Levy II, M., Carmichael, G.R.: Impact of biomass burning on troposperic $\mathrm{CO}, \mathrm{NO}_{\mathrm{x}}$, and $\mathrm{O}_{3}$. J. Geophys. Res. 105, 6633-6653 (2000)

IMD: India Meteorological Department, Indian Daily Weather Report, Kanyakumari observatory for the year 2007-2009 (2010)

Lelieveld, J., Crutzen, P.J., Ramanathan, V., Andreae, M.O., Brenninkmeijer, C.A.M., Campos, T., Cass, G.R., Dickerson, R.R., et al.: The Indian Ocean Experiment: widespread air pollution from south and southeast Asia. Science 291, 1031-1036 (2001)

Mills, G., Buse, A., Gimeno, B., Bermejo, V., Holland, M., Emberson, L., Pleijel, L.: A synthesis of AOT40based response functions and critical levels of ozone for agricultural and horticultural crops. Atmos. Environ. 41, 2630-2643 (2007)

Mittal, M.L., Hess, P.G., Jain, S.L., Arya, B.C., Sharma, C.: Surface ozone in the Indian region. Atmos. Environ. 41, 6572-6584 (2007)

Nair, P.R., Chand, D., Lal, S., Modh, K.S., Naja, M., Parameswaran, K., Ravindran, S., Venkataramani, S.: Temporal variations in surface ozone at Thumba $\left(8.6^{\circ} \mathrm{N}, 77^{\circ} \mathrm{E}\right)$-a tropical coastal site in India. Atmos. Environ. 36, 603-610 (2002)

Naja, M., Lal, S.: Changes in surface ozone amount and its diurnal and seasonal patterns from 1954-55 to 1991-93, measured at Ahamedabad (23º N), India. Geophys. Res. Lett. 23, 81-84 (1996)

Nishanth, T., Satheesh Kumar, M.K., Valsaraj, K.T.: Variations in surface ozone and NOx at Kannur: a tropical, coastal site in India. J. Atmos. Chem. 69, 101-126 (2012)

Ohara, T., Akimoto, H., Kurokawa, J., Horii, N., Tamaji, K., Yan, X., Hayasaka, T.: An Asian emission inventory of anthropogenic emission sources for the period 1980-2020. Atmos. Chem. Phys. 7, 4419-4444 (2007)

Rai, R., Agrawal, M., Agrawal, S.B.: Assessment of yield losses in tropical wheat using open top chambers. Atmos. Environ. 41, 9543-9554 (2007)

Royal Society: Ground-level ozone in the 21st Century: Future trends, Impacts and Policy Implications. The Royal Society, London. Science Policy report 15/08 October (2008)

STA, State Transport Authority: Report on District Wise Number of Registered Vehicles in the State April 2010. Government of Tamil Nadu, India (2010)

Streets, D.G., Bond, T.C., Carmichael, G.R., Fernandes, S.D., Fu, Q., He, D., Klimont, Z., Nelson, S.M., et al.: An inventory of gaseous and primary aerosol emissions in Asia in the year 2000. J. Geophys. Res. 108(D21), 8809 (2003). doi:10.1029/2002JD003093

Van Dingenen, R., Dentener, F.J., Raes, F., Krol, M.C., Emberson, L., Cofala, J.: The global impact of ozone on agriculture crop yields under current and future air quality legislation. Atmos. Environ. 43, 604-618 (2009) 
Velasco, E.: Estimates for biogenic non-methane hydrocarbons and nitric oxide emissions in the Valley of Mexico. Atmos. Environ. 37, 625-637 (2003)

Vingarzan, R.: A review of surface ozone background levels and trends. Atmos. Environ. 38, 3431-3442 (2004)

Wahid, A.: Influence of atmospheric pollutants on agriculture in developing countries: a case study with three new varieties in Pakistan. Sci. Total Environ. 371, 304-313 (2006)

Wang, T., Cheung, V.T.F., Anson, M., Li, Y.S.: Ozone and related gaseous pollutants in the boundary layer of eastern China: overview of the recent measurements at the rual site. Geophys. Res. Lett. 28, 2373-2376 (2001)

Wang, X., Mauzerall, D.L.: Characterizing distributions of surface ozone and its impact on grain production in China, Japan and South Korea: 1990 and 2020. Atmos. Environ. 38, 4383-4402 (2004) 